\title{
SEKOLAH YANG RESPONSIF GENDER (STUDI PADA SMKN 5 KENDARI)
}

\author{
Ety Nur Inah \\ Fakultas Tarbiyah dan Ilmu Keguruan, Institut Agama Islam Negeri Kendari \\ ety_nurinah@yahoo.com \\ Rudiyanto \\ Fakultas Tarbiyah dan Ilmu Keguruan, Institut Agama Islam Negeri Kendari \\ rudiyanto@gmail.com \\ Aeni Kharunnisa \\ Fakultas Tarbiyah dan Ilmu Keguruan, Institut Agama Islam Negeri Kendari \\ Aeni_kharunnisa@gmail.com
}

\begin{abstract}
This study aimed to reveal how the description of gender responsive school management as well as gender responsive facilities and infrastructure in teacher secondary schools, especially at state vocational high school 5 Kendari. This research is a qualitative research with data collection through interviews. The results of the study illustrated that school management that is gender responsive in terms of the placement of the principal's position broadly opens opportunities for teachers to occupy strategic positions regardless of male or female gender but based on competence and responsibility and has implemented gender equality and justice in all things, as well as in service in schools provide opportunities for male and female teachers to attend training outside the school and apply disaggregated data in order to facilitate obtaining information about the school in this case school administration. In addition to school management that has been gender responsive and the results of the research show that the tools that support learning are facilities and infrastructure that are also gender responsive, including the use of classrooms, toilet rooms, prayer rooms (mosques) and laboratory room seats.
\end{abstract}

Keywords: school; management; gender responsive; facilities and infrastructure

\begin{abstract}
Abstrak
Penelitian ini bertujuan untuk mengungkapkan bagaimana gambaran manajemen sekolah yang responsive gender serta sarana dan prasarana yang responsive gender di sekolah menengah keguruan khususnya pada sekolah menengah keguruan negeri 5 Kendari. Penelitian ini merupakan jenis penelitian kualitatif dengan pengumpulan data melalui wawancara. Hasil penelitian menggambarkan bahwa manajemen sekolah yang responsive gender dalam hal penempatan jabatan kepala sekolah membuka secara luas kesempatan bagi guru untuk menduduki jabatan yang strategi tanpa melihat jenis kelamin laki-laki atau perempuan tetapi berdasarkan kompetensi dan tanggung jawab dan telah menerapkan kesetaraan dan keadilan gender dalam segala hal, begitu pula dalam pelayanan di sekolah memberikan peluang bagi guru laki-laki maupun perempuan untuk mengikuti pelatihan di luar sekolah serta menerapkan data terpilah guna memudahkan mendapatkan informasi tentang sekolah dalam hal ini administrasi sekolah. Selain manajemen sekolah yang sudah responsive gender dan dari hasil penelitian menunjukkan perangkat yang mendukung pembelajaran yakni sarana dan prasarana juga sudah responsive gender antara lain penggunaan ruang kelas, ruang Toilet (WC), ruang tempat beribadah (mesjid) serta tempat duduk ruang laboratorium.
\end{abstract}

Kata Kunci: sekolah; manajemen; responsif gender; Sarana dan Prasarana 


\section{A. Pendahuluan}

Salah satu kebutuhan untuk mewujudkan kondisi kesetaraan dan keadilan gender adalah melakukan penelitian yang berbasis gender, penelitian ini dilakukan tidak hanya pada satu jenis kelamin melainkan kedua-duanya yakni laki-laki dan perempuan. Selain itu gender adalah menyangkut peran social yang terbentuk dalam masyarakat, selain itu gender adalah perbedaan prilaku antara laki-laki dan perempuan bukan secara biologis melainkan terbentuk melalui proses soaial dan cultural, gender dapat berubah sementara jenis kelamin tidak berubah ${ }^{1}$. Salah satu lembaga yang dapat diharapkan ikut serta dalam pengambilan kebijakan yang responsive gender adalah Sekolah. Hal ini sesuai dengan Undang - undang No. 20 tahun 2003, pasal 8 tentang System Pendidikan Nasional yang telah dikutip oleh peneliti bahwa lembaga yang dimaksud adalah sekolah yang responsive gender yaitu suatu sekolah yang baik aspek akademik, social, aspek lingkungan fisik maupun lingkungan masyarakatnya memperhatikan secara seimbang kebutuhan spesifik antara kebutuhan laki - laki maupun kebutuhan perempuan.

Sekolah merupakan lembaga yang berperan penting untuk merubah pola pikir peserta didik termasuk perilaku - perilaku yang dianggap bias gender., dalam hal ini sekolah di harapkan bisa adil gender tanpa terkendala oleh nilai-nilai sosial budaya yang kadang bias gender. Hal ini sejalan dengan hasil penelitian sebelumnya yang dilakukan oleh Dimas Wijaksana Nur Faisal (Journal Student UNY, 2018) tantang Implementasi Program Sekolah Responsif Gender di SMPN 15 Yogjakarta, dimana menunjukkan hasil: 1) implementasi program sekolah responsif gender dalam pembelajaran terdapat lima aspek yaitu : konsep ruang kelas disesuaikan dengan kebutuhan gender, RPP berwawasan gender, sumber belajar yang dapat diakses oleh laki-laki dan perempuan, media pembelajaran yang tidak bias gender dan metode pembelajaran yang memberikan kesempatan sama terhadap laki-laki dan perempuan, 2) sarana dan prasarana responsif gender dapat dilihat dari ruang laktasi untuk ibu menyusui, pembagian kamar mandi antara laki-laki dan perempuan seimbang dan unit kesehatan sekolah untuk laki-laki dan perempuan, 3) kegiatan penunjang program sekolah responsif gender yaitu kegiatan rutin dan insidental dan 4) faktor pendukung dari dalam sekolah adalah manajemen sekolah responsif gender serta pembelajaran berwawasan gender. $^{2}$

Kementrian Pendidikan Nasional bertekad melayani kebutuhan pendidikan mulai dari pendidikan anak usia dini, pendidikan dasar, pendidikan menengah, sampai kejenjang pendidikan tinggi.

Meningkatnya kualitas pelayanan pendidikan khususnya di sekolah harus dapat dinikmati oleh peserta didik baik laki-laki maupun perempuan dalam kerangka kesetaraan dan berkeadilan gender. Adil tidaklah harus sama jumlah, yang terpenting adalah bagaimana relasi gender dapat dibangun dalam ranah kehidupan di setiap jenis dan jenjang pendidikan terutama pada sebuah lembaga penddidikan dalam hal ini skolah.

Sekolah adalah lembaga pendidikan yang perlu menerapkan keadilan antara laki-laki dan perempuan dalam hal pelayanan, khusus Sekolah Menengah Keguruan(SMK) dalam hal ini SMKN 5 Kendari yang respontif gender namun belum terdata, belum tersedianya ruang menyusui khusus untuk ibu hamil Hal inilah yang mendorong penulis untuk meneliti Sekolah Yang Responsif Gender.

Gender adalah seperangkat peran yang diberikan kepada perempuan dan laki-laki bukan secara biologis, peran ini berubah sesuai dengan budaya, usia dan latar belakang etnis. ${ }^{3}$ Selain itu Gender juga didefenisikan sebagai suatu konstruksi social yang mengkategorikan

\footnotetext{
${ }^{1}$ Grewal,L dan Kaplan,C, An Introduction Womwn Studies, New York:Mc Graw Hill Companies Inc,2002).

${ }^{2}$ Dimas Wijaksana Nur Faisal, Implementasi Program sekolah Responsif Gender di SMPN 15 Yogjakarta, Journal Student UNY, 2018

3 .Mosser, J.C,Gender dan Pembangunan, Yogjakarta, Rifka Annisa WCC dan Pustaka Pelajar, 1996
} 
perempuan dan laki-laki berdasarkan persepsi dan perasaan, gender bervariasi berdasarkan waktu, tempat, budaya serta pengalaman hidup ${ }^{4}$.

Selain peran antara laki-laki dan perempuan yang sama maka perlu pula ditinjau dari perlakuan dalam hal ini keadilan dan kesetaraan gender harus setara dan seimbang. Keadilan gender adalah keadilan dalam memperlakukan perempuan dan laki-laki sesuai kebutuhan mereka yang mencakup perlakuan yang setara atau yang berbeda tetapi diperhitungkan ekuivalen dalam hal hak, kewajiban, kepentingan dan kesempatan. ${ }^{5}$ Sedang kesetaraan gender berarti kesamaan bagi laki-laki dan perempuan untuk memperolah kesempatan serta hak-haknya sebagai manusia agar mampu berperan dan berpartisipasi dalam kegiatan, politik, hukum, ekonomi , pendidikan dan social budaya dalam menikmati hasil pembangunan tersebut. ${ }^{6}$

Dari defenisi diatas hal ini sesuai dari hasil penelitian wawancara Wakil Kepala Sekolah Bidang Kurikulum sebagai wakil kepala sekolah saat Bapak Ir. H. Rahman Garussu, MM sebagai Kepala Sekolah SMKN 5 Kendari yang berakhir pada bulan Januari 2018 menurut beliau;

Sejak berdirinya sekolah ini tahun 2009 telah menerapkan konsep Gender, khususnya dalam penempatan jabatan beliau tidak membeda-bedakan antara laki-laki dan perempuan sesuai dengan kompetensinya dan bertanggung jawab yakni dapat dilihat dari penempatan jabatan Wakil Kepala Sekolah(Wakasek) dimana ada 4 Wakasek yakni ; Wakasek Bidang Kurikulum, Wakasek Bidang Kesiswaan, Wakasek Bidang Sarana dan Prasarana serta Wakasek Bidang Hubungan Masyarakat yang terdiri dari Wakasek Bidang Kurikulum Bapak Ahmad Yunan, S.Pd,MP, Wakasek Sarana dan Prasarana Bapak Yetmen, S.Pd, Wakasek Bidang Kesiswaan Ibu Ariyati, SP, M.Si, dan Wakasek Bidang Hubungan dan Masyarakat Ibu Siti Ramla, S.Si, seimbang antara laki-laki dan perempuan ${ }^{7}$.

Dari hasil wawancara di atas dapatlah dicermati bahwa panerapan konsep Gender di sekolah tersebut telah diterapkan khususnya dalam penempatan jabatan, hal ini sejalan dengan defenisi gender berkaitan dengan kualitas dan relasi yang dibentuk dalam hubungan kekuasaan, pembagian kerja yang lebih luas yang diperkuat oleh system budaya, agama, dan masyarakat ${ }^{8}$.

\section{B. Temuan Penelitian}

\section{B.1 Sekolah Yang Responsif Gender}

Sekolah merupakan salah satu lembaga yang berperan penting untuk merubah pola pikir peserta didik yang dianggap bias gender. Nugroho (2008:29) menyampaikan bahwa keadilan gender merupakan sebuah proses untuk memperlakukan secara adil terhadap lakilaki dan perempuan, atas dasar tersebut berarti tidak ada lagi pembakuan peran, beban ganda, subordinasi, marginalisasi dan kekerasan terhadap jenis kelamin tertentu, ${ }^{9}$ Oleh karena itu sekolah adil gender memegang peran dan fungsi yang strategis dalam mempersiapkan peserta didik agar dapat mengembangkan multi intelegensiannya secara optimal tanpa terkendali oleh nilai-nilai soail budaya yang kadang bias gender. Unruk memperjelas sekolah yang responsive gender memiliki cici-ciri yakni : ${ }^{10}$

\footnotetext{
${ }^{4}$ Bradley, H, Gender, Cambridge, Polity Press , 2007

${ }^{5}$ Dwi Edi Wibowo, Jurnal Nuwazah, Vol.2, No.1, Juli 2010,h.190

${ }^{6}$ Iswah Adriana, Jurnal Tadris, Vol.4, No. 1, 2009

${ }^{7}$ Ahmad Yunan,wawancara19 Juli 2018)

${ }^{8}$ Ostergaard,L, Gender dan Development Apractical Guide, Surakarta, UNS Press, 1992

${ }^{9}$ Nugroho.R, Gender dan Strategi Pengarus Utamaanya di Indonesia, Yogjakarta, Puataka Pelajar, 2008.

10 Dwi Edi Wibowo, Jurnal Nuwazah, Vol.2, No.1, Juli 2010
} 
1. Memiliki Kepemimpinan yang dilakukan secara horizontal dan team work kooperatif yang ramah terhadap perbedaan. Hal ini sudah dilaksanakan di SMKN 5 Kendari, dari wawancara Wakil Kepala Sekolah Bidang Kurikulum mengatakan bahwa :

"Kepemimpinan Kepala Sekolah selama menjabat baik kepala sekolah yang lama maupun kepala sekolah yang sekarang sudah melaksanakan kepemimpinan secara horizontal, artinya dalam mengambil tindakan untuk kepentingan sekolah tetap melakukan koordinasi dengan bawahan baik guru laki-laki maupun guru perempuan tanpa membeda-bedakan dan dibicarakan secara team untuk memutuskan sesuatu yang berkaitan dengan kepentingan sekolah $^{11}$.

Selain kepemimpinan kepala sekolah juga dalam pemilihan ketua kelas mereka juga melaksanakan tanpa melihat jenis kelamin melainkan secara demokratis dan tidak memihak pada satu jenis kelami saja melainkan siapa saja yang memang punya kemampuan dan bertanggung jawab dapat melaksanakan tugas sebagai ketua kelas maupun ketua kelompok tetap diperuntukkan baik laki-laki maupun merempuan ${ }^{12}$

Dari hasil wawancara oleh peneliti dapatlah disimpulkan bahwa sekolah tersebut sudah menuju ke sekolah yang responsive gender oleh karena sudah melakukan tanpa bias gender.Artinya sekolah tersebut sudah dapat dikatakan telah menerapkan konsep gender yang selama ini diupayakan agar dapat terwujud kesetaraan dan keadilan gender di sekolahsekolah.

2. Pembagian peran atau posisi fleksibel tergantung pada kebutuhan, kesempatan, komitmen dan kualitas . Pernyataan ini senada dengan ungkapan bapak Kepala Sekolah SMKN 5 Kendari bahwa :

"Dalam pembagian dan penempatan peran dan posisi saya tidak membeda-bedakan baik guru laki-laki maupun guru perempuan dalam memduduki jabatan yang penting sesuai dengan kompetensi dan tanggung jawab yang dimilikinya ${ }^{13}$.

Ungkapan ini sejalan dengan pendapat Sarjanadin Naudu mengatakan bahwa dalam pembagian peran atau posisi kepala sekolah menyesuaikan kebutuhan dan kesempatan yang sesui dengan kompetensi dan tanggung jawab yang telah diberikan sehingga dalam penempatan posisi tidak membeda-bedakan laki-laki maupun perempuan ${ }^{14}$.

Dari hasil wawancara Kepala Sekolah dan Guru menyebutkan bahwa penempatan posisi sudah menerapakan kesetaraan gender tidak lagi membeda-bedakan yang penting baik guru maupun staf sesuai dengan konpetensi yang di miliki baik laki-laki maupun perempuan.

Selain konsep gender sudah diterapkan sesuai cirri-ciri sekolah yang responsive gender maka perlu pula memperhatikan kebutuhan peserta didik baik yang laki-laki maupun perempuan di sekolah. Adapun indicator yang dijadikan acuan untuk mewujudkan sekolah yang responsive gender adalah :

\section{B.1a Adanya Pembelajaran Yang Responsif Gender}

Pembelajaran yang responsive gender adalah proses pembelajaran yang memberikan perhatian seimbang bagi kebutuhan laki-laki dan perempuan. Menurut Remiswal (2013:27) menyatakan bahwa pelaksanaan pendidkan/pembelajaran gender yaitu harus bersifat nonseksis, mendorong sifat kritis, tidak diskriminatif dan berlangsung dengan demokratis, seperti pembelajaran non seksis dalam berdiskusi guru tidak membeda-bedakan antara kelompok laki-laki maupun perempuan saja, artinya dalam satu kelompok terdiri dari lakilaki dan perempuan, serta guru memberikan kesempatam kepada laki-laki maupun

11 Ahmad Yunan,wawancara19 Juli 2018

12 Laode Ardiyansyah, wawancara 17 september 2018

${ }^{13}$ Susi Husen, wawancara 17 september 2018

${ }^{14}$ Sarjanadin,Naudu,wawancara 17 september 2018 
perempuan untuk menjadi ketua kelompok. ${ }^{15}$ Selain dalam berdiskusi dalam kegiatan sekolah da;am hal prngolahan makanan juga tidak membeda-Obedakan antara laki-laki dengan perempuan . Hal ini dipertegas dari hasil wawancara Ketua Prodi Agro Bisnis Teknologi Pengolah Hasil Pertanian mengatakan :

"Kami sebagai pendidik sudah mulai memperhatikan kebutuhan peserta didik untuk memperoleh akses partisipasi dan manfaat yang sama dari kegitan belajar di sekolah, misalnya dalam kegiatan Pengolah Makanan Membuat Kue Rosales dimana siswa laki-laki dan perempuan semua terlibat di dalamnya, siswa perempuan membuat adonan kue Rosales dan siswa laki-laki yang menggoreng adonan tersebut yang biasanya dilakukan oleh anak perempuan. ${ }^{16}$

Pernyatan diatas di perkuat oleh siswa/siswa mengatakan bahwa kami tidak di bedabedakan dalam hal pembelajaran missal dalam hal pembuatan tentang pengolahan makanan $^{17}$.

Selain itu peserta didik baik laki-laki dan perempuan memperolah hak dan kewajiban yang sama dalam pemberian sangsi jika terbukti melanggar aturan sekolah, maka diserahkan ke Guru Bimbingan Penyuluhan (BP) dan diberi sangsi sesuai dengan pelanggaran yang dilakukan oleh peserta didik tersebut ${ }^{18}$.

\section{B.1b Adanya Perencanaan Pembelajaran Responsif Gender}

Pada pembelajaran yang responsive gender guru harus memperhatikan berbagai pendekatan belajar yang memenuhi kaidah kesetaran dan keadilan gender, baik melalui proses perencanaan pembelajaran, intraksi belajar mengajar, pengolahan kelas maupun dalam evaluasi hasil belajar. Perencanaan pembelajaran yang responsif gender adalah rencana mengajar yang memperhitungkan kebutuhan khusus yang dimiliki oleh peserta didik laki-laki dan perempuan dalam proses pembelajaran. Hal ini senada dengan ungkapan Ibu Harneli, S.Pd mengatakan bahwa :

"Dalam merencanakan pembelajaran di kelas kami tidak membeda-bedakan peserta didik laki-laki maupun perempuan dalam melaksanakan suatu kegiatan pembelajaran, misalnya menghafal sejarah tentang masuknya Agama Islam ke Indonesia tidak mesti laki-laki yang bisa hafal tapi peserta didik perempuanpun mampu untuk menghafal ${ }^{19}$. Selain pernyataan di atas yang diungkapkan oleh guru sejarah peserta didik dalam hal ini Yunita juga mengatakan bahwa dalam perencanaan pembelajaran yang diberikan oleg guru tidak semata-mata diperuntukkan dengan melihat jenis kelamin melainkan sudah disamakan antara peserta didik laki-laki maupun perempuan jadi tidak ada yang bias gender (tidak hanya diperuntukkan untuk satu jenis kelamin saja). ${ }^{20}$

\section{B.1c Adanya Penataan Ruang Kelas Yang Responsif Gender}

Ruang kelas selain memperhatikan pemenuhan standar operasional untuk proses pembelajaran juga diharapkan memenuhi kebutuhan spesifik laki-laki dan perempuan . Menurut Wibowo (2010:193) mengemukakan bahwa salah satu indikator yang dapat menciptakan sekolah responsif gender adalah adanya konsep ruang kelas yang sensitif gender $^{21}$, Ciri khas dari konsep ruang kelas sensitif gender diantaranya adalah meja belajar peserta didik terdapat penutup didepannya, hal ini berfungsi sebagai pelindung untuk peserta

\footnotetext{
${ }^{15}$ Remiswal, Menggugah Partisipasi Gender di Lingkungan Komunitas Lokal, Yogjakarta, Graha Ilmu,

${ }^{16}$ Ibu Wa Ode Kuliati, wawancara 9 Agustus 2018

${ }^{17}$ Farhan,siswa SMKN 5 Kendari wawancara 17 September 2018

18 Bapak Baharuddin,wawancara, 15 Agustus 2018

${ }^{19}$ Ibu Harneli, Wawancara, 6 September 2018

${ }^{20}$ Yunita, siswi SMKN 5 Kendari, Wawancara 17 September 2018

${ }^{21}$ Dwi Edi Wibowo, Jurnal Nuwazah, Vol.2, No.1, Juli 2010
} 
didik perempuan. Selain itu Tata letak Ruang kelas sangat penting pula untuk meningkatkan efektifitas proses pembelajaran. Letak tata ruang ini penting dalam rangka mengaktifkan pembelajaran seperti yang di katakan oleh ibu Ariyati :

"Latak tata ruang dalam mengajar dapat meningkatkan peserta didik belajar lebih kreatif dan efektif, missal dalam berdiskusi letak kursi disesuaikan dengan tempat yang dapat mendorong partisipasi anak laki-laki dan anak perempuan dapat menyampaikan pendapatnya dan menghilangkan rasa malu atau rendah diri sehingga letak kursi di model $^{22}$.

Dari hasil observasi peserta didik dalam melaksanakan proses pembelajaran guru juga kadang merubah letak kursi sepmisal dalam berdiskusi letk kursi terkadang di model huruf U agar suasana belajar lebih nyaman baik untuk anak laki-laki maupun anak perempuan.

Dari uraian di atas berupa hasil wawancara dan hasil observasi member gambaran bahwa tata letak ruang kelas sangat penting serta letak kursi dalam proses belajar mengajar juga perlu diperhatikan oleh karena seorang guru yang inovatif untuk mengolah tataletak ruang kelas akan menjadi lebih nyaman dan kondusif bagi tumbuhnya partisipasi peserta didik baik laki-laki maupun perempuan.

\section{B.1d Adanya Intraksi Kelas Yang Responsif Gender}

Intraksi kelas merupakan salah satu factor yang paling menentukan dalam mencapai keberhasilan pembelajaran ${ }^{23}$. Menurut Widodo (2010) sebagaimana dikutib Achmad Haidir,dkk " dalam intraksi di ruang kelas guru perlu menyadari bahwa peserta didik laki-laki dan perempuan membutuhkan perhatian yang berlainan ${ }^{24}$, hal ini dipertengas oleh Guru Biologi bahwa :

" Intraksi antara peserta didik laki-laki dan perempuan tidak boleh dibatasi selama mereka dapat mengeluarkan pendapat yang berkaitan dengan pembelajaran tidak boleh didominasi oleh peserta didik laki-laki saja tetapi perempuan tetap dilibatkan ${ }^{25}$.

Dari hasil wawancara menunjukkan bahwa intraksi antara guru dan peserta didik tidak boleh dibatasi apalagi jika melihat dari jenis kelamin. Pembagian peran dan tanggung jawab di kelas sangat berdampak pada proses intraksi mereka di kelas. Guru perlu mengupayakan tidak adanya dominan salah satu jenis kelamin, oleh karena menjadi sangat penting untuk menciptakan intraksi kelas yang benar-benar menggambarkan adanya kesataraan dan keadilan gender.

Pernyataan diatas dipertengas oleh guru Teknologi Hasil Pertanian yang sekaligus merangkap sebagai Ketua Prodi Agribisnis THP yang mengatakan :

"Dalam kelas membutuhkan perhatian antara laki-laki dan perempuan khususnya dalam pembagian peran dan tanggung jawab khususnya dalam mengolah hasil pertanian, Misalnya dalam pembuatan Bakso mereka membagi peran yang saling berintraksi untuk menyelesaikan tugas yang diberikan oleh guru mereka ${ }^{26}$.

\section{B.2 Manajement Yang Responsif Gender}

Manajemen yang responsif gender ialah sebuah model manajemen yang menyediakan akses yang sama bagi laki-laki maupun perempuan untuk berperan didalamnya serta menghasilkan manfaat yang sama bagi keduanya ${ }^{27}$,

\footnotetext{
22 Ibu Ariyati, Wawancara 13 September 2018

${ }^{23}$ Dwi Edi Wibowo, Jurnal Nuwazah, Vol.2, No.1, Juli 2010

${ }^{24}$ Achmad Hidir,dkk, Pendidikan Responsif Gender Di Kabupaten Rohan Hilir, Jurnal Primary, Vol.5,No.2, Oktober 2016-Maret 2017,ISSN:2303-1514

${ }^{25}$ Ibu Lilis, Wawancara 13 September 2018

${ }^{26}$ Ibu Waode Kuliati, Wawancara 6 September 2018

${ }^{27}$ Siti Hikmah Anas, Manajemen Berbasis Madrasyah , PSW UIN Sunan Kalijaga Yogjakarta, 2005
} 
Sistem manajemen pendidikan di sekolah pada umumnya kurang memperhatikan aspek kesetaraan dan keadilan gender dalam penyusunan rencana pelaksanaan serta dalam evaluasi ${ }^{28}$. Namun berbeda dengan system manajemen yang dilaksanakan pada Sekolah Menengah Keguruan Negeri 5 Kendari, dimana system manajemen mereka sudah melaksanakan kesetaran dan keadilan gender, hal ini dapat di kutip dari hasil wawancara Bapak Kepala Sekolah tersebut yang mengatakan bahwa (Susi Husen, wawancara 9 Juli 2018)"Sistem manajemen yang diterapkan berkepihakan antara laki-laki dan perempuan baik pada peserta didiknya maupun pada guru-guru serta para stafnya. Sejalan dengan pernyataan Mainizar dalam Ratna Mega Wangi (2004) bahwa "kesetaraan gender adalah persamaan perlakuan tanpa memandang gender dengan memberikan perlakuan khusus dalam arti ada perbedaan biologis yang berakibat social ${ }^{29}$. Disamping itu sebagian besar sekolah kurang sensitive terhadap pemenuhan kebutuhan khusus bagi anak perempuan seperti kebutuhan fasilitas ruang khusus bagi anak perempuan pada waktu mereka sedang mendapat menstruasi, ketersediaan air, tempat sampah pembalut wanita dsb.

Dari uraian di atas dipertegas oleh Bapak Yetmen, "Khusus kebutuhan perempuan yang berupa ketersediaan ruang khusus bagi siswa perempuan belum disediakan tempat sampah khusus pembalut wanita. Untuk memenuhi kebutuhan tersebut maka perlu diupayakan adanya penyusunan perencanaan dan anggaran yang responsive gender ${ }^{30}$. Salah satu contoh anggaran yang disediakan untuk mengikuti pelatihan-pelatihan khusus untuk guru baik guru laki-laki maupun guru perempuan anggaran sudah disiapkan, menurut Kepala Sekolah bahwa :

"Dalam kebijakan penganggaran bagi guru untuk mengikuti pelatihan sudah ada tanpa membeda-bedakan guru laki-laki maupun guru perempuan, seperti yang mengikuti pelatihan Otomotif yang biasanya diberangkatkan guru laki-laki tapi kenyataannya guru perempuan yang kami berangkatkan untuk mengikuti pelatihan tersebut oleh karena dianggap mampu untuk mewakili sekolah yakni Ibu Erna Deri Pakanan ${ }^{31}$.

Salah satu yang harus diperhatikan dalam manajemen sekolah yang responsive gender adalah anggaran dan kebijakan sekolah yang responsive gender, dalam rangka mendukung keberhasilan sekolah tersebut.

\section{B.2a Aspek Manajemen Sekolah Yang Responsif Gender}

Adapun indicator dari aspek manajemen sekolah yang responsive gender antara lain :

1. Memiliki Kesempatan dan Peran Yang Sama atau Setara Dalam Menduduki Jabatan Laki-laki dan perempuan memiliki kesempatan dan peran yang sama atau setara dalam mengendalikan system pendidikan di sekolah, misalnya kesempatan antara laki-laki dan perempuan untuk menjadi Kepala Sekolah, Wakil Kepala Sekolah dan Pengawas Sekolah. Kesempatan ini harus terbuka lebar bagi guru perempuan maupun guru lakilaki. Dasar penentuan seseorang dapat atau tidak dapat mengendalikan sistem pendidikan di sekolah bukanlah jenis kelamin seseorang tetapi lebih ditentukan oleh kompetensinya .

Dari keempat Wakil Kepala Sekolah tersebut yang telah ditunjuk untuk menduduki jabatan oleh Bapak Ir. H. Rahman Garusu, MM pada waktu itu masih menjabat sebagai Kepala Sekolah sejak tahun 2009 sampai Januari 2018. Ke empat Wakil Kepala Sekolah yang peneliti wawancara yakni :

1) Wakil Kepala Sekolah Bidang Kurikulum mengatakan bahwa : dalam penempatan jabatan kepala sekolah tidak membedakan antara laki-laki dan perempuan, namun

\footnotetext{
${ }^{28}$ Dwi Edi Wibowo, Jurnal Nuwazah, Vol.2, No.1, Juli 2010

${ }^{29}$ Ratna Mega Wangi, Membiarkan Berbeda, Bandung, Mizan, 1999

${ }^{30}$ Bapak Yetmen,Wawancara 6 September 2018

${ }^{31}$ Bapak, Susi Husen, Kepala Sekolah SMKN 5 Kendari, Wawancara 5 Juli 2018
} 
berdasarkan kompetensi yang dimiliki serta tanggung jawab yang dapat dipertanggung jawabkan ${ }^{32}$.

Salah satu tupoksi wakasek bidang kurikulum pada poin ke empat yakni mengkordinir kegiatan belajar mengajar termasuk pembagian tugas guru, jadwal pelajaran, evaluasi belajar, dan sebagainya. Untuk mencapai tujuan dan fungsi tersebut menurut beliau tidak membedakan antara laki-laki dan perempuan untuk dapat melaksanakan kegiatan tersebut yang menjadi tugas dari jabatan yang diembannya yakni sebagai Wakil Kepala Sekolah Bidang Kurikulum.

2) Wakil Kepala Sekolah Bidang Sarana dan Prasarana mengatakan: ditempatkan sebagai wakasek bidang sarana dan prasarana kepala sekolah mellihat dari kemampuan atau kompetensi yang dimiliki seseorang baik guru laki-laki maupun guru perempuan, dimana kesempatan dan peran yang sama atau setara.serta memiliki hak yang sama. ${ }^{33}$

3) Wakil Kepala Sekolah Bidang Kesiswaan bahwa jabatan yang diberikan oleh kepala sekolah juga berdasarkan atas kompetensi dan tanggung jawab yang dimiliki seorang guru baik guru laki-laki maupun guru perempuan, jabatan sebagai Wakasek Bidang Kesiswaan pada umumnya diduduki oleh laki-laki namun di SMKN 5 ini memang sudah menerapkan keadilan gender atau perlakuan hak antara laki-laki dan perempuan , Kepala sekolah telah berusaha memberi ruang dan kesempatan untuk para guru untuk menduduki jabatan-jabatan startegis, kepercayaan tersebut ternyata dapat dijalankan oleh para perempuan yang memang notabene selain di sector public mereka juga punya tanggung jawab di sector domestic ${ }^{34}$.

4) Wakil Kepala Sekolah Bidang Hubungan dan Masyarakat ditunjuknya sebagai Wakasek Humas cukup berat untuk jabatan yang diembannya sebagai seorang perempuan yang mana pada umumnya di jabat oleh seorang laki-laki tetapi kenyataanya lagi-lagi kepala sekolah mempercayakan pada seorang perempuan untuk memduduki jabatan yang strategis di sekolah ini, ${ }^{35}$ Menurut kepala sekolah penunjukan memang berdasarkan kompetensi dan tanggung jawab yang dimiliki oleh seseorang tanpa melihat jenis kelamin laki-laki atau perempuan, ${ }^{36}$

Sedangkan tanggung jawab sebagai Wakasek Humas memang cukup berat dimana salah satu Tugas dan Fungsinya yang harus dilaksanakan dapat dilihat pada Tugas dan Fungsi Wakil Kepala Sekolah Bidang Hubungan Masyarakat di bawh ini antara lain "Membantu yang karena tugas-tugasnya tidak dapat langsung memberikan informasi kemada masyarakat atau pihak-pihak yang memerlukannya., seperti yang tertera pada Tugas dan Fungsi Wakasek Hubungan Masyarakat, beliau mengatakan :" Tugas dan Fungsi yang di berikan oleh Kepala Sekolah memang cukup berat tapi demi tanggung jawab dan komitmen untuk dapat melaksanakan tugas tersebut maka kami tetap melaksanakan tugas tersebut. ${ }^{37}$

Dari uraian diatas dapatlah disimpulkan bahwa pemimpin atau personal yang bisa mengisi jabatan-jabatan strategis di sekolah tidak harus laki-laki tetapi perempuan memiliki hak dan kesempatan yang sama untuk ikut berkompetisi dalam mengisi struktur organisasi di sekolah khususnya Ketua Prodi pada 5 prodi.

Dari ke lima jabatan tersebut yang semuanya diduduki oleh perempuan walaupun diawali banyak yang meragukan apakah tugas dan tanggung jawab untuk memduduki jabatajabatan strategis itu bisa dijalan dengan baik, namun kenyataannya mereka dapat

\footnotetext{
${ }^{32}$ Bapak Ahmad Yunan, Wawancara 6 September 2018

${ }^{33}$ Bapak Yetmen, Wawancara 17 September 2018

${ }^{34}$ Ibu Ariyati, M.Si, Wawancara 6 September 2018

${ }^{35}$ Ibu Sitti Ramla, Wawancara 26 Agustus 2018

${ }^{36}$ Bapak Susi Husen, Kepala Sekolah, Wawancara di SMKN 5, 9 Agustus 2018

${ }^{37}$ Ibu Siti Ramla, Wakil Kepala Sekolah Bidang HUmas, Wawancara di SMKN 5 , 6 Juli 2018
} 
melaksanakan dengan baik denganpenuh rasa tanggung jawab yang mereka miliki di masingmasing prodi. Menurut mereka salah satu dari ke 5 ketua prodi yakni Ketua Prodi Teknologi Otomotif Sepeda Motor yang di beri kepercayaan oleh Kepala sekolah mengatakan bahwa :

"Saya sebagai Ketua Prodi Teknologi Otomotif Sepeda Motor kurang percaya diri oleh karena yang seharusnya menduduki jabatan tersebut adalah guru laki-laki , namun kenyataannya kepala sekolah menunjuk saya untuk jabatan tersebut di karenakan selain kompetensi yang saya miliki juga saya sudah pernah mengikuti Pelatihan Keahlian Ganda Otomotif seiring waktu saya menjalani jabatan ini dan ternyata saya mampu untuk melakasanakan jabatan tersebut yang mana peserta didiknya semuanya laki-laki tetapi tidak mengurangi kepercayaan diri saya selaku Ketua Prodi sekaligus sebagai guru Otomotif Perbengkelan.. Jadi memang dalam penempatan jabatan tidak perlu melihat jenis kelamin tetapi kompetensi dan tanggung jawab yang telah diberikan oleh kepala sekolah khususnya SMKN 5 Kendari. $^{38}$

2. Memiliki Kesempatan dan Peran Yang Sama atau Setara Dalam Melaksanakan Pelayanan di Sekolah.

Peran Laki-laki dan perempuan memiliki kesempatan yang sama atau setara dalam membina, mengarahkan dan melaksanakan pelayanan pendidikan di sekolah dan dapat memperoleh manfaat yang sama dari kesempatan dan peran tersebut. Misal kesamaan kesempatan untuk mengikuti pendidikan dan pelatihan serta kesamaan kesempatan untuk memperoleh manfaat dari pelatihan tersebut. Pernyataan ini juga telah dilaksanakan di SMKN 5 Kendari oleh Kepala Sekolah mengatakan bahwa :

Kesempatan yang diberikan untuk mengikuti Pelatihan atau Pendidikan dalam rangka Peningkatan Profesional Guru di buka secara luas baik untuk guru laki-laki maupun guru perempuan dan tetap memperhatikan kompetensi yang dimiliki oleh guru tersebut. Misal diberinya kesempatan pada guru perempuan untuk mengikuti Pelatihan tentang Keahlian Komputer dan Multi Media yang notabene tidak mempunyai pengetahuan tentang media computer namun kepala sekolah menunjuk untuk mengikuti Pelatihan tersebut oleh karena semua guru mempunyai hak untuk diikutkan dalam pelatihan atau pendidikan dalam rangka memenuhi pelayanan pendidikan di sekolah tersebut.

Menurut ibu Ismawati Puspaoni dipilihnya untuk mewakili sekolah mengikuti Pelatihan dan Pendidikan selama 10 bulan buat ibu cukup berat tapi katanya perempuan juga harus maju utamanya dalam hal IT sehingga mendorong saya untuk menerima tanggung jawab yang diberikan oleh kepala sekolah untuk ikut pelatihan tersebut, dan Alhamdulillah saya dapat ilmu dan bisa menerapkan di sekolah demi memenuhi kebutuhan peserta didik untuk mengetahui penggunaan IT khususnya Komputer dan Multi Media. ${ }^{39}$

3. Sekolah Memberi Penghargaan terhadap Hasil Unjuk Kerja Tenaga Pendidik maupun Tenaga Kependidikan.

Dalam pemberian penghargaan kepada tenaga pendidik maupun kependidikan menurut kepala sekolah tidak didasari pada jenis kelamin namun berdasarkan kompetensi yang mereka miliki tanpa terkendala oleh hambatan cultural terkait peran yang mereka jalankan. Bagi guru perempuan maupun laki-laki semua diberi peluang oleh karena di sekolah tersebut sudah melaksanakan kesetaraan dan keadilan gender. Salah satu diberinya penghargaan kepada guru yang mempunyai inovasi dalam pembelajaran. Misal Ibu Waode Kuliati dalam pembelajaran tentang Teknologi Pengolahan . Adapun yang di olah antara lain

${ }^{38}$ Ibu Erna Deri Pakanan, Ketua Prodi Teknologi Otomotif Sepena Motor, Wawancara di SMKN 5, 27 September 2018

39 Ibu Ismawati Puspaoni, Guru Komputer sekaligus senbagai Ketua Prodi Tehnik Komputer dan Jaringan, Wawancara di SMKN 5, 6 September 2018. 
pembuatan krupuk ubi jalar yang sudah dipasarkan di took-toko dan diberi nama "Stik Ubi Jalar SMKN 5 Kendari oleh Kepala Sekolah memberikan mereka Sertifikat sebagai Penghargaan dari hasil karya mereka..

4. Tersedianya Data Terpilah Pada Sekolah Menengah Keguruan Negeri 5 Kendari

Salah satu ruang lingkup Manajemen Sekolah Yang Responsif adalah Administrasi Sekolah yang merupakan gudangnya data dan salah satu data yang harus ada adalah data tentang jumlah peserta didik, jumlah guru ataukah jumlah guru yang menduduki jabatan yang kesemuanya ini di istilahkan dalan sekolah yang responsive gender adalah Data Terpilah.

Data Terpilah sangatlah penting bagi suatu sekolah oleh karena melalui data terpilah dapat memberikan informasi dalam melakukan perencanaan, implementasi maupun monitoring dan evaluasi pendidikan yang responsive gender. Salah satu contoh Data Terpilah adalah data tentang Jumlah Guru Tidak Tetap berdasarkan Jenis Kelamin , dapat dilihat pada table berikut ini:

Dari uraian di atas peneliti menyimpulkan bahwa Manajemen Sekolah Yang Responsif Gender sangatlah penting baik dalam hal peran dan kesempatan untuj menduduki jabatan baik jabatan strategis di sekolah, pemberian penghargaan dan perolehan pelayanan di sekolah yang semuanya mempunyai hak yang sama antara laki-laki maupun perempuan., khusus di Sekolah Menengah Keguruan Negeri 5 Kendari sudah menerapka yang namanya Sekolah Yang Responsif Gender yang di dalamnya antara lain adanya Manajemen Sekolah Yang Responsif Gender .

\section{B.3 Gambaran Sarana dan Prasarana Yang Responsif Gender}

Untuk mewujudkan kesetaraan dan keadilan gender di bidang pendidikan perlu dimulai dari lingkungan sekolah. Adapun model sekolah yang responsif gender salah satu yang harus diperhatikan adalah tersedianya sarana dan prasarana yang responsif gender ${ }^{40}$

Dalam praktik sehari-hari selalu muncul pembedaan peran gender yang berakibat terjadinya bias gender, yakni suatu pandangan yang membedakan peran, kedudukan serta tanggung jawab laki-laki dan perempuan dalam kehidupan keluarga, masyarakat dan pembangunan. Oleh karena itu diperlukan upaya terwujudnya keadilan dan kesetaraan gender yakni suatu kondisi yang setara dan seimbang bagi laki-laki dan perempuan dalam memperoleh kesempatan dan akses pembangunan. ${ }^{41}$ Tersedianya sarana dan prasarana sekolah perlu dirancang tidak memperhatikan perbedaan kebutuhan antara laki-laki dan perempuan, misalnya ketersediaan toilet (WC) antara peserta didik laki-laki dan perempuan, tangga gedung sekolah $\mathrm{dll}^{42}$

Untuk mewujudkan kesetaran .dan keadilan gender di bidang pendidikan perlu dimulai dari lingkungan sekolah. Adapun komponen-komponen bidang pendidikan yang responsive gender antara lain kurikulum, bahan ajar serta sarana dan prasarana.

Salah satu yang menunjang pembangunan di suatu lembaga sekolah yang responsive gender adalah tersedianya sarana dan prasarana yang yang responsive gender. Sedangkan terkait dengan pengaturan sarana dan prasarana yang responsive gender pemerintah mengeluarkan Permendiknas No. 24 Tahun 2007 dimana sarana dan prasarana tersebut meliputi : ruang belajar, tempat beibadah, ruang toilet, ruang olah raga, ruang laboratorium bengkel kerja, perpustakaan serta sumber belajar lainnya ynag diperlukan untuk menunjang proses pembelajran.

\footnotetext{
${ }^{40}$ Marzuki, Sarana dan Prasarana Sekolah Yang Responsif Gender,staffnew.uny.ac.id, diunduh 20 - 102008

41 Ibid,h.3

${ }^{42}$ Rustam Efendi, Kesetaraan Gender dalam Pendidikan, Jurnal Al -Maiyyah,Vol,07,No.2,Thn.2014
} 
Dari uraina di atas hasil penelitian yang peneliti lakukan pada Sekolah Menengah Keguruan Negeri 5 Kendari penulis memperolah data tentang sarana dan prasarana yang responsive gender sesuai dengan Permendiknas No. 24 Tahun 2007 antara lain :

\section{Penggunaan Ruang Belajar Yang Responsif Gender}

Ruang belajar merupakan salah satu tempat dimana peserta didik memperoleh pelajaran dengan baik.. Oleh karena itu tata letak ruang belajar sangat penting untuk meningkatkan efektifitas proses pembelajaran. Tata letak ruang belajar perlu merespon kebutuhan khusus anak perempuan dan anak laki-laki.. Dari hasil wawancara guru Komputer dan Jaringan mengatakan :

"Tata letak ruang belajar tempat duduk dalam kelas bagi anak perempuan dan anak laki-laki ditata agar dapat mendorong anak perempuan mau dan mampu menyampaikan pendapatnya dan menghilangkan rasa malu dan rendah diri. ${ }^{43}$

Dari hasil wawancara diatas dapatlah disimpulkan bahwa ruang belajar haruslah di sesuaikan antara kebutuhan peserta didik perempuan dan laki-laki demi penunjang hasil yang lebih optimal.

\section{Ruang Toilet Yang Responsif Gender}

Fasilitas yang secara tidak langsung menunjang pelaksanaan pembelajaran adalah tersedianya runag toilet yang responsive gender artinya toilet (WC) yang ada disekolah sudah memenuhi kebutuhan peserta didik, yakni memisahkan antara toilet laki-laki dengan toilet perempuan. Di sekolah menengah keguruan negeri 5 Kendari sudah menggunakan Toilet yang memisahkan antara perempuan dan laki-laki, dari hasil wawancara peneliti dengan Bapak Wakil Kepala Sekolah Bidang Sarana dan Prasarana mengatakan :

"Sarana dan Prasarana yang ada di sekolah kami sudah sebagain memisahkan antara peserta didik laki-laki dengan perempuan, salah satunya adalah penggunaan toilet bagi peserta didik yang sudah memisahkan antara peserta didik laki-laki dengan perempuan begitu pula dengan Toilet (WC) Guru dan Staf sudah memisahkan antra toilet laki-laki dengan perempuan ${ }^{44}$.

Selain hasil wawancara wakil kepala sekolah bidang sarana dan prasarana didukung pula oleh peserta didik yang mengatakan ruang Toiltet (WC) yang diperuntukkan oleh peserta didik sudah dipisahkan antara toilet laki-laki dengan toilet perempuan sehingga kami perempuan merasa nyaman dalam toilet tersebut ,namun masih ada kekurangan oleh karena tempat sampah khusus untuk pembalut perempuan jika datang bulan (haid) belum disiapkan khusus $^{45}$.

Menurut Hartini, guru olah raga mengatakan kami guru sudah merasa nyaman dengan di bedakannya ruang toilet laki-laki dan perempuan sehingga kami merasa tidak terganggu jika berada di dalam toilet tersebut disamping itu dalam ruang toilet disiapkan cermin yang mana merupakan kebutuhan kami terkhusus kami perempuan $^{46}$. Untuk kebersihan toilet sudah bersih salah satu indikatornya didalam toilet baik untuk peserta didik maupun guru dan staf tong sampah sudah disiapkan (hasil observasi peneliti)

Selain sarana dan prasarana ruang toilet (WC) yang dimiliki sekolah menengah keguruan negeri 5 Kendari juga memiliki tempat beribadah.

\section{Ruang Tempat Ibadah Yang Responsif Gender}

Tempat Ibadah adalah salah satu tempat yang dapat menunjang pembelajaran dalam hal peningkatan ahlak bagi peserta didik, baik peserta didik laki-laki maupun perempuan .

\footnotetext{
${ }^{43}$ Ibu Ismawati Puspaoni, Guru TKJ, Wawancara di SMKN 5, 26 September 2018

${ }^{44}$ Bapak Yetmen, Wawancara, 17 September 2018)

${ }^{45}$ Kiki Saputri, Peserta Didik,Wawancara, 17 September 2018)

${ }^{46}$ Ibu Hartini, Guru Olah Raga, wawancara, 17 September 2018)
} 
Adapun yang dimaksud tempat ibadah adalah Mesjid sebagai tempat ibadah Umat Islam yang sebagian besar peserta didiknya beragama Islam.

Mesjid adalah rumah tempat ibadah ummat Islam. Yang diartikan tempat sujud. Mesjid merupakan sarana pendidikan Islam karena bagaimanapun pendidikan agama Islam tidak dapat terlepas dari jasa besar mesjid. , seperti shalat berjamaah, khusus di skolah menengah keguruan negeri 5 shalat berjamah merek selalu lakukan yakni salat dhuha dan salat duhur dimana perserta didik baik laki-laki maupun perempuan sudah dipisahkan , seperti yang diutarakan Bapak Baharuddin senagai guru Pendidikan Agama Islam mengatakan :

"Mesjid yang ada di SMKN 5 sudah lberdiri sejak tahun 2014 dimana diperuntukkan untuk acara-acara keagamaan atau hari-hari besar umat islam dan yang tidak pernah ditinggalkan adalah shalat dhuha secara berjamaah, dan mesjid tersebut sudah memakai tirai sebagai pemisah antara laki-laki maupun perempuan yang mana mesjid sudah secara tidak langsung sudak responsive gender. Adapun nama mesjidnya adalah Mesjid Ar - Rahman. ${ }^{47}$

Selainpernyataan guru PAI dipertegas oleh Wakasek Bidang Sarana dan Prasarana bahwa Mesjid sebagai tempat beribadah sudah memperhatikan kebutuhan peserta didiknya baik laki-laki maupun perempuan di mana mulai tempat Wudhu sampai ruang mesjid sudah memisahkan kebutuhan laki-laki dan perempuan ${ }^{48}$.

Pernyataan diatas juga didukung oleh peserta didik baik yang laki-laki maupun yang perempuan yang mengatakan :

"Mesjid adalah sarana tempat beribadah di mana tata ruang di dalamnya sudah responsive gender dalam hal ini sudah memisahkan antara laki-laki dan perempuan selain itu juga memisahkan tempat wudhu sekalipun belum dalam bentuk ruangan tapi sudah dipisahkan sehingga kami laki-laki mengambil air wudhu tidak merasa terganggu. ${ }^{49}$

Selain tempat wudhu kebersihan dalam ruang mesjidpun tertata dengan rapih.Sehingga dianjurkan untuk senantiasa memakmurkan masjid-masjid sebagai rumah Allah dengan menjalankan shalat berjamaah.

\section{Ruang Laboratorium Yang Responsif Gender}

Sarana Laborotorium merupakan salah satu peninjang dalam proses belajar mengajar, ruang tata letak tempat duduk laboratorium juga di rancang sedemikian rupa guna memenuhi kebutuhan peserta didik antara laki-laki dan perempuan. Menurut Wakasek Sapras bahwa “ tempat duduk di laboratorium memiliki ukuran dan bentuk yang nyaman baik untuk anak laki-laki maupun untuk anak perempuan. ${ }^{50}$

Dari uraian di atas dapatlah disimpulkan bahwa untuk menunjang pembangunan di bidang pendidikan khususnya di lembaga sekolah maka perlu adanya sarana dan prasarana untuk menunjang pembelajaran bagi peserta didik yang memperhatikan kebutuhan antara peserta didik laki-laki dan perempuan dan bagi guru dan staf juga perlu diperhatikan dalam rangka memenuhi kebutuhan ruang-ruang khusus untuk melayani perempuan yang memiliki kebutuhan lebih kompleks ketimbang laki-laki.

\section{Penutup}

\footnotetext{
47 Bapak Baharuddin, Guru PAI, Wawancara, 17 September 2018

${ }^{48}$ Bapak Yetmen, Wakasek Bid.Sapras, Wawancara, 9 September 2018

${ }^{49}$ Ilham Riadin, Pesrta Didik, Wawancara, 26 September 2018

${ }^{50}$ Bapak Yetmen, Wakasek Bid. Sapras, 9 September 2018
} 
Gambaran Manajemen Sekolah yang Responsif Gender pada Sekolah Menengan Keguruan Negeri 5 Kendari di peroleh dari hasil penelitian adalah Memiliki Kesempatan dan Peran Yang Sama atau Setara Dalam Menduduki Jabatan; laki-laki dan perempuan memiliki kesempatan dan peran yang sama atau setara dalam mengendalikan system pendidikan di sekolah misalnya kesempatan antara guru laki-laki dan perempuan untuk menduduki jabatan Wakil Kepala Sekolah, hasil penelitian menunjukkan dari ke 4 Wakil Kepala Sekola yang di tunjuk oleh kepala sekolah berimbang antara laki-laki dan perempuan yakni Wakil Kepala Sekolah Bidang Kurikulum dan Bidang Sarana dan Prasarana di jabat oleh laki-laki sendangkan Wakil Kepala Sekolah Bidang Kesiswaan dan Bidang Hubungan Masyarakat di jabat oleh perempuan yang mana dasar menunjukkan yang dilakukan oleh kepala sekolah berdasarkan Kompetensi yang dimiliki dan Tanggagung jawab tanpa melihat jenis kelamin yang artinya kepala sekolah sudah menerapkan kesetaraan dan keadilan gender dalam menduduki jabatan (sudah responsive gender).selain itu dalam memberikan pelayanan di sekolah, guru di beri peluang untuk mengikuti pelatihan juga tanpa melihat jenis kelamin serta telah diterapkannya data terpilah untuk memudahkan memberi informasi tentang data sekolah yang sudah responsive gender.

Sarana dan Prasarana yang ada di sekolah menengah keguruan negeri 5 ini juga sudah menerapkan kesetaraan dan keadilan gender dimana telah memperhatikan kebutuhan baik peserta didik laki-laki maupun kebutuhan guru dan staf yang laki-laki maupun perempuan . Adapun sarana dan prasarana yang sudah responsive gender antara lain penggunaan ruang belajar , ruang Toilet (WC), ruang tempat ibadah serta tempat duduk di laboratorium..

\section{DAFTAR PUSTAKA}

Ace Suryadi, Kesetaraan Gender Dalam Pendidikan, Bandung: Ganesindo, 2004

Achmad Hidir,dkk, Pendidikan Responsif Gender Di Kabupaten Rohan Hilir, Jurnal Primary, Vol.5,No.2, Oktober 2016-Maret 2017,ISSN:2303-1514

Bogdan, Robert C, and Bikley, Sari Knoop, Qualitative Research in Education an Introduction $t \quad o$ Theory and Methdos, London: Allyn and Bacon, 1998, p. 4-7

Bradley, H, Gender, Cambridge: Polity, 2007

Cholid Narbuko dan Abu Ahmadi, Metode Penelitian, Bumi Aksara, Jakarta, 2005

Depdiknas, Modul 1 : Panduan Mewujudkan Manajemen Berbasis Sekolah yang Responsif Gender,2008)

Depdiknas, Panduan Sekolah Berwawasan Gender, Jakarta, Dekdisnas 2008.

Dwi Edi Wibowo, Sekolah Berwawasan Gender, Jurnal Muwazah, Vol.2 No.i, Juli 2010

Endang Sumiarni, Jender dan Feminisme, Yokyakarta: Wonderful Publising Company, 2004

Eni Purwati dan Hanun Asrohah, Bias Gender dalam Pendidikan Islam, Surabaya: Alpha, 2005.

Fakih,M, Analisis Gender dan Transformasi Sosial, Insist Press, Jakarta, 2008

Grewal,I \& Kaplan, C, An Introduction Women"s Studies, New York: McGraw-Hill Companies Inc, 2002

Iswah Adriana, Jurnal Tadris Volume 4 Nomor 1, 2009

John M.Echols dan Hassan Shadly,Kamus Inggris Indonesia, Jakarta, PT.Gramedia,2005.

Mainizar, Keluarga dan Kesetaraan Gender Dalam Perspektif islam, Jurnal Marwah (Jurnal Perempuan, Agama, dan Gender, Vol.III,No.6 Desember , 2004

Mansour Fakih, Analisis Transfoemasi Sosial, Yokyakarta: Pustaka Pelajar 1999

Marzuki, Sarana dan Prasarana Sekolah Yang Responsif Gender,staffnew.uny.ac.id, diunduh $20-10-2008$

Moore,H.L, Feminisme dan Antropologi, Yayasan Obor Indonesia, Jakarta, 1998 
Moser, CON, Gender Planning and Development: Teori, Practice, and Training, London: Routledge, 1993

Mosse,J,C, Gender dan Pembangunan, Rifka Annisa WCC \& Pustaka Pelajar, Yogjakarta, 1996

Mujamil Qomar, Manajemen Pendidikan Islam, Malang, Erlangga, 2007.

Nurhaeni, Reformasi Kebijakan Pendidikan Menuju Kesetaraan dan Keadilan Gender, UNS Press, Surakarta, 2009

Ostergaard, L, Gender and Development Apractical Guide, Routledge, New York, 1992

PERMENDEKNAS No. 24 Tahun 2007

Philip Robinson, Sosiologi Pendidikan. Jakarta: Rajawali Press, 1981

Ratna Megawangi, Membiarkan Berbeda,Bandung: Mizan, 1999.

Retno Susilowati, Menguak Pengarusutamaan Gender dalam Pendidikan ,Jurnal Studi Gender Palestren, Vol. 3 Nomor 1, 2010.

Rustam Efendi, Kesetaraan Gender dalam Pendidikan, Jurnal Al - Maiyyah, Vol.07, N0.2 , Thn. 2014

Rustam Efendi, Kesetaraan Gender dalam Pendidikan, Jurnal Al Maiyyah,Vol,07,No.2,Thn.2014

Sanafiah, Faisal.Metode Penelitian Sosial, Jakarta : Erlangga, 2000, h. 122

Sumardi Subrata, Metode Penelitian, Raja Grafindo Persada, Jakarta, 2003

Tim Penyusun, Membangun Relasi Setara Antara Perempuan dan Laki-laki Melalui Pendidikan Islam, Jakarta: Direktorat Jenderal Pendidikan Kementrian Agama Australia Indonesia Partnership, 2010 